Open Access

\title{
Precarious knowledge workers in China's social transformation-a study of editors in the Chinese publishing industry
}

Jianhua Yaoi

Correspondence:

yaojianhua@fudan.edu.cn

School of Journalism, Fudan

University, 400 Guoding Road,

Shanghai 200433, China

\begin{abstract}
Contributing to contemporary studies on knowledge workers, this paper aims to conceptualize the four critical challenges for editors in the Chinese publishing industry under the framework of political economy. These challenges, as a result of fundamental social changes, including technological, political and economic ones, and, most importantly, changes in class relations and power dynamics are the following: challenges related to technological change, challenges of how to follow the political principle in the media marketization process, challenges brought about by the smashing of the work-unit system, and challenges resulting from internal divisions within knowledge workers. Moreover, by incorporating findings discovered in the case studies of two publishing houses in Shanghai, this paper addresses the wider social relationship between communication and the institutional power structure in which editors, and knowledge workers in general, are situated.
\end{abstract}

Keywords: Knowledge workers, Editors, Chinese publishing industry, Media marketization, Social transformation

\section{Introduction}

The study of knowledge workers has raised a number of important questions for academics and policymakers. Bell (1999) maintains that with the rise of a society dependent on intellectual technology, particularly on the production and distribution of theoretical information, a new class of leaders-a genuine knowledge class of welltrained scientific and technical workers-is rising to prominence. With the emphasis on meritocracy based on education and skills in the production and distribution of information, knowledge workers have successfully become central figures in this new political and economic system.

Many thinkers have supplemented this tradition, such as Herbert Schiller (1973), Harry Braverman (1974), Manuel Castells (1996), and Vincent Mosco (2009). Compared to industrial workers, knowledge workers-professional, skilled and presumably middle-class-play an increasingly critical role in the global market. Mosco and McKercher (2008) point out that with knowledge workers occupying a large share of jobs in the developed world and with dramatic growth in their numbers in poorer nations as well, they are becoming active in the labor movement globally.

(C) The Author(s). 2017 Open Access This article is distributed under the terms of the Creative Commons Attribution 4.0 International License (http://creativecommons.org/licenses/by/4.0/), which permits unrestricted use, distribution, and reproduction in any medium, provided you give appropriate credit to the original author(s) and the source, provide a link to the Creative Commons license, and indicate if changes were made. 
However, the decline in the power of labor worldwide, as a result of both technological and institutional convergence, has turned much of the world's labor force, including knowledge workers, into precarious workers. As Ross (2009) maintains, no one, not even those in traditional professions, can any longer expect a fixed pattern of employment in the course of their lifetime. There has been a gradual increase in contingent employment. For this reason, both industrial workers in low-end services and knowledge workers in high-wage occupations are under tremendous pressure to anticipate and prepare for a future in which they can still compete in the changing marketplace. Knowledge workers are pressured by long hours, deadline speedups, and a division of labor which reduces employee autonomy. Worse still, they are increasingly confronted with the radical uncertainty of their futures, the temporary nature of their work contracts and their isolation from any protective framework of social insurance.

Contributing to contemporary studies on knowledge workers, this paper aims to demonstrate the network of power relations and institutional contexts in which knowledge workers are situated, as well as to conceptualize the challenges confronting them under the framework of political economy. Specifically in the Chinese publishing industry, four critical challenges are brought about by both media reform and social transformation in the digital era. These challenges include technological, political and economic ones, and, most importantly, changes in class relations and power dynamics.

\section{Literature review}

In "The Laboring of Communication," Mosco points out that despite a number of outstanding exceptions, "[the issue of] media labor and class formation is a blind spot in communication studies" (Mosco 2006:493). However, the growth of employment in communication industries and the technological and institutional changes unleashed by corporate concentration and digitalized capitalism have alerted communication scholars to "the changing nature of work and of worker organization," in order to advance our understanding of those broader transformative historical processes that both shape and are carried out through media and communications (Mosco 2008:121). In this sense, labor studies help better understand the broader transformative historical process of media and communications when their control and deployment are examined from the analysis of social relations, as well as the possibilities for and the obstacles to emancipatory social changes within a comprehensive and compelling theoretical framework.

First, it is important to acknowledge that knowledge workers, who play a critical role in the current social transformation, are an important component of the working class in China (Zhu and Dai 2009). To specify, according to Marx, who defines class at the point of production, the working class is a definite social group, whose common identity is rooted in the non-ownership of the means of production, selling labor power for wages, and having status as an employee (Braverman 1974). Following Marx's definition, in the Chinese context, the working class is comprised of "people who, by their physical strength and skills, directly or indirectly operate the tools of production to produce physical products, provide labor service or assistance to such production or service, and are supervised by managers" (Lu 2002:127). To categorize, in China, the working class is considered to manufacture material commodities, such as clothes, gas, chemicals, and machines, and to offer non-material commodities, which include knowledge, information, management, and services. 
In the transition to a market economy, the Chinese working class is also in the process of changing and restructuring (Jin 1998). Before the economic reform since the late 1970s, the common conception of the Chinese working class was that it was a social group comprising urban laborers who did not possess any means of independent production or reproduction of their livelihoods, living primarily from wages based on employment. Thus, the main body of the working class consisted of industrial workers. Nevertheless, China's economic reform has broadened such a concept and led to a new understanding of "the working class," which includes four social divisions: workers providing physical labor (blue collar workers), workers providing mental labor (white collar workers), intellectuals conducting educational or scientific work, and civil servants and managerial cadres in the public sector (Liu 2001). That is to say, the working class in China has expanded and now includes: workers in state-owned, collective, and private enterprises; the peasantry; intellectuals; cadres; cadres and intellectuals in the countryside; private entrepreneurs working on their own; private entrepreneurs with enterprises of their own; soldiers; college students; and the underclass composed of migrant laborers, beggars, and etc.

In brief, the labor of knowledge workers, like that of industrial workers, is also considered to make a crucial contribution to China's socialist construction; and therefore, knowledge workers engaged in education, science and technology, and medical services, including media workers, are an indispensible part of the working class (Zhu 1994; Chang 1998). From this viewpoint, the idea of a single, unified class of workers began to emerge in China.

Second, Zhang and Peng (2001) maintain that knowledge workers are not regarded as a separate social group. They are part of the working class, and their interests are intrinsically linked to other members of the working class, to which they attach themselves through their work. Accordingly, it is essential to examine the identities, consciousness, and behavior of knowledge workers in association with those of industrial workers not only because the labor of knowledge workers needs to be treated as a form of work to be combined with manual labor in the production of a commodity but also due to the common challenges that confront the working class as a collective.

Furthermore, the social analysis of knowledge workers is specifically concerned with the relationship between the working class (including both knowledge workers and industrial workers) and the state. On the one hand, the state still possesses the power to manage and organize both knowledge workers and industrial workers. In Class in China, Wortzel (1987) implies that neither knowledge workers nor industrial workers are fully able to articulate their material interests or to translate these interests into political programs or changes in the allocative process in China because important economic decisions, with regard to the direction of the national economy or of a stateowned enterprise, may not be undertaken without the approval of the state. Therefore, both knowledge workers and industrial workers are relegated to the same conditions, as subordinate to the central authority of the state, which possesses social resources.

On the other hand, in Working in China, Lee (2007) asserts that labor policy reforms have reshaped the legal context of work and employment, and, as a result, the political control of the state over workers and workplaces has declined. The gradual dismantling of the "iron rice bowl" (tiefanwan, also known as the permanent employment system for state employees) began with the introduction of the labor contract in the early 
1980s and became universal mandate in 1995 when China's first Labor Law was implemented. This is significant because employment relations are regulated by the Labor Law rather than by state policies. Accordingly, labor conflicts are resolved according to "The Regulations of the People's Republic of China on Settlement of Labor Disputes in Enterprises". Effective in 1993, these regulations identify a three-stage procedure of mediation, arbitration, and litigation (Ho 2003), implying that labor market mechanisms have replaced labor administration in the allocation of labor. Although the increasing importance of laws and markets partially frees workers from their past economic and political dependence on the state, it nevertheless enhances their dependence on market forces.

\section{Methodology}

This paper principally draws on approaches that rest upon qualitative traditions to critically analyze challenges facing knowledge workers, particularly editors in the publishing industry, during China's on-going social transformation. Such approaches include archival studies and semi-structured interviews.

\section{Archival studies}

In this research, I have examined a large number of newspapers, magazines, pamphlets, government and business reports, and press releases as the main sources of data collection. First, I have collected and studied various Chinese government sources to trace recent development in China's media industries. The most important sources include government reports, white papers, and policy documents, such as those of the Central Propaganda Department of the CCP (Chinese Communist Party), the State Administration of Press, Publication, Radio, Film and Television, and the State Council Information Office. For the authoritative information on labor and employment relations, I have consulted official statistics from the Ministry of Labor and Social Security and the State Council.

Third, yearbooks are also useful sources. They are considered the most comprehensive and professional sources in China, based on their quality, availability, and costs (Vallas, Finlay, and Wharton 2009). I have used the annual China Labor Statistical Yearbook, Chinese Journalism Yearbook, China Publishers' Yearbook, and Yearbook of China Information Industry as references. They provide a comprehensive description of the annual growth of China's publishing industry and the technological development of China's industrial relations.

Fourth, it is essential to supplement official statistics with reports from non-governmental organizations or written by university professors. As Hong (2008) argues, there is a possibility, even a likelihood, that the official statistics have been manipulated or that they are mistaken because sometimes they also serve a propaganda function. Therefore, in my case, I have paid specific attention to several important non-governmental reports in the fields of China's publishing industry and labor relations. Such reports include "The Annual Report on China's Media Development Index" by the School of Journalism, Renmin University of China; "The Report on the Development of Chinese Media Industries" by the Chinese Academy of Social Sciences and Tsinghua University; "The Report on Chinese Labor Issues" by the Labor and Social Security Forum, Beijing; "The Report on Human Resources Development in Shanghai" by the Human Resources Research Center and the Population and Development Research Center, the Shanghai Academy of Social Sciences. 


\section{Semi-structured interviews}

This paper is based on two case studies of publishing houses in Shanghai. As Yin (2009) maintains that case studies allow not only for the examination of particular complexities in a case but also enable researchers to gain insights into larger systematic issues-an appropriate methodology for researchers who want to look at an issue using both close- and long-focus lenses.

\section{Basic interview questions}

As arranged, I first contacted the managers (lingdao) of both the publishing houses to gain permission for my interviews with the editors. After obtaining their permission, I selected from the pool of editors recommended by the managers to obtain interviews with individuals of different age, gender, and occupational rank. I conducted interviews only after each editor had agreed to the terms specified in the Letter of Information and the Letter of Consent. Altogether, I interviewed four editors from each publishing house.

My interviews included both structured and open-ended questions, and each interview lasted for 2-3 hours. Most interviews were conducted in the publishing houses where the editors worked. My interview questions focused on the following:

1. As an editor, if there are changes to your work process, how do you deal with them?

(a) Specify the changes in your work process, if possible.

(b) What role has technology played in your work process changes? Are you aware of the challenges brought about by the rapid development of information and communication technologies, especially with the rise of digital media?

(c) To what extent do you recognize the challenges toward the propaganda function of the media sector brought about by the media marketization process?

2. How would you define the changes in your social welfare benefits, and social status in general, over the past few decades? What do you perceive to be the reasons for these changes?

3. Do you perceive any differences within the organization between senior editors and junior editors? If so, what are the differences?

\section{Supplementary interviews}

I supplemented these two case studies with three interviews with chief editors who work in other major publishing houses in Shanghai. In addition, I also conducted two interviews: one with an official from the Shanghai Publication Bureau and another with an official from the Shanghai Publishers Association. These interviews, when combined with the original data I collected from my case studies, helped to comprehensively understand the precarious conditions in which editors are situated. My questions for the government official from the Shanghai Publication Bureau concentrated on how government groups at all levels in China (central, provincial, and local) are responding to the challenges with which editors are now faced. I was also interested to learn more about the policies that have been implemented, and will be implemented, to help editors better cope with these challenges. My questions to the official from the Shanghai Publishers Association mainly explored the activities organized by the association to connect editors of different age, gender, job title, and educational background from 
different publishing houses, and, more importantly, to investigate the institutional arrangements that can unite editors. Table 1 summarizes the basic background information of each interview participant.

\section{Ethics in the semi-structured interviews}

There are two ethical issues in the semi-structured interviews that need to be addressed.

First, as Berg (2007) emphasizes, subjective decisions are involved in every step of the case study-from deciding which case to examine to the final hours of writing up the findings. He also suggests that subjective decisions can lead to both sample bias and measurement bias in data collection and analysis. For example, sample bias, in my case, might occur if participants are not chosen randomly from the population or the publishing house being studied is not representative. At the same time, measurement bias is likely to arise, given that the definitions of concepts involved in the interviews, such as "democratic," "authoritarian," and "commercial," are somewhat individually contingent. However, the statements above are true, not in the sense that every possible means should be tried to avoid succumbing to any subjective decisions, but that decisions, throughout every research phase, should be made mindfully and criteria chosen carefully (Stake 2000).

In my interviews, I adopted a mixed-methods approach, also known as triangulation, to conduct my research, dedicating every effort to clearly spelling out the choices that have been made and the direction that has been taken. Denzin and Lincoln (2008) argue that studies that rely on multiple sources of data are more likely to be accurate. Triangulation-examining the same research questions by using multiple sources (in this paper: documents, observations, and interviews)-offers a more accurate picture of what is being studied.

The second ethical issue relates to the anonymity of the participants. Stake (2000) maintains that any qualitative research which is interested in people's personal views and circumstances potentially poses risks to its participants, leading to their loss of employment, self-esteem, or their standing in the community. The anonymity of the participants in my interviews is even more significant, due to the fact that participants can

Table 1 Interviewees with their basic background information

\begin{tabular}{lllll}
\hline & Gender & Age & Educational background & Category \\
\hline 1 & M & 46 & Bachelor & Editor \\
2 & F & 37 & Master & Editor \\
3 & F & 55 & Bachelor & Editor \\
4 & F & 33 & Master & Editor \\
5 & M & 25 & Bachelor & Editor \\
6 & F & 31 & Master & Editor \\
7 & M & 32 & Master & Editor \\
8 & M & 55 & Bachelor & Editor \\
9 & F & 34 & Doctorate & Chief editor \\
10 & M & 58 & Bachelor & Chief editor \\
11 & M & 59 & Doctorate & Chief editor \\
12 & M & 48 & Master & Government official \\
13 & F & 43 & Bachelor & Government official \\
\hline
\end{tabular}


be easily identified with the specific information provided. To handle this situation, I adopted several important methods to protect the participants.

To elaborate, upon first contact, I informed potential participants of their right to withdraw from my research at any time-before the interview, during, or even after it. I reminded the participants that if they chose to withdraw their information, it would be deleted from the database immediately and permanently. Both the Letter of Information and the Letter of Consent contained details about their right to withdraw, and the letters were distributed before the interviews. Also, pseudonyms were given to protect each participant's identity in writing up the findings.

\section{Precarious editors in the publishing industry}

According to Mosco, social life is comprised of the mutual constitution of structure and agency: "structures are constituted out of human agency, even as they provide the very 'medium' of that constitution" (Mosco 2009:185). Structure, as Giddens argues, is regarded as the rules and resources recursively implicated in social reproduction. Structure is out of time and space and marked by an "absence of subject" (Giddens 1984:25). However, social systems, in which structure is recursively implicated, also comprise the situated activities of human agents that are reproduced across time and space. Therefore, the analysis of social systems incorporates the ideas of agency, social relations, and social practice into the political economic analysis of social structures.

In this regard, structures and agents are not two independently given sets of phenomena; they are interconnected in the ongoing patterning of social life (Mosco 2009). This paper addresses an interconnection between structures (the dominant Chinese political, economic, and social structures) and agents (editors in the Chinese publishing industry), attempting to bridge the gap between theoretical perspectives that foreground structure and those that emphasize action and agency.

Furthermore, both Mosco and Giddens underscore the interconnection between structures and agents with the prominence it gives to social change-a process that is described as the way structures are produced and reproduced by human agents who act through the medium of the structure. According to Hobsbawn (1973), structural analysis can never be fully understood without comprehending the stabilizing and disruptive elements that either lead to the maintenance of a system or to the inevitability of social change. Following these arguments, this paper connects the challenges facing Chinese knowledge workers, editors in particular, to the broader ongoing social transformation in China. In more detail, editors in the Chinese publishing industry are challenged by the following four critical issues.

\section{Technological change in China}

Since the 1990s, with the goal of more fully integrating China into the global political economy, the nationwide economic reform has shifted its concentration to the promotion of information technology, particularly, the widespread expansion of the Internet. The past twenty years has witnessed the extensive application of information technology by professionals, managers, and media workers in China. The consequences to the publishing industry are twofold. On the one hand, it is much easier today for editors to use databases, manipulate text and quantitative data, generate tables and graphic displays, 
and utilize analytical software. Editors are also able to communicate with one another through computer networks, refresh their knowledge, upgrade their professional skills at a relatively low cost, and gain quick access to external databases and communication networks that can be either used independently or in conjunction with internal databases (Zhang 2004). As a result, both organizational and national boundaries have been blurred.

On the other hand, in recent years, as technological development has advanced, editors have experienced numerous challenges resulting from the dramatic changes in both their work process and their working conditions. In the publishing industry, the de-skilling effects of new technology are so prevalent that they have devalued much of the professional knowledge and abilities of editors.

To specify, first, editors' work has been simplified along with the de-skilling effects of new technology. In an interview with $\mathrm{Li}$, he maintained:

I am completely unsatisfied with my work in the publishing house. I graduated from one of the leading universities in China, and my major was editing and publishing. When I first entered the publishing house, I thought I would be very successful due to my educational background and professional training. I was wrong. I have never been allowed to choose which books to publish or to edit. Even highly profitable books cannot be published without the manager's approval. I only work on books assigned by the manager and check for typos. Actually, I am very good at advertising and promoting new books. I can design very attractive posters, and also know a lot about marketing. It is frustrating, however, that these skills are becoming less and less important due to the use of professional software in the publishing house. I am not the only person who has this problem. To be honest, a lot of junior editors feel the same way.

Undoubtedly, the application of information technology has caused the de-skilling trend to move up the occupational ladder. De-skilling is not just a feature of industrial workers but of knowledge workers as well. For most editors, the introduction of media digitalization has largely removed them from the conception stage of production. In most Chinese publishing houses, editors are mainly responsible for checking typos on the screen and reading drafts to ensure their political correctness. There is a growing awareness among editors that new technology has devalued much of their professional knowledge and the abilities upon which they had once prided themselves (Liu 2006). Such professional knowledge and abilities for editors include having a solid background of grammar and sentence rules, accurate understanding of the logic of language, and the ability to connect book contents to readers' interests.

Second, in association with the de-skilling effects of digital media, job opportunities for most of the editors have greatly decreased. McKercher (2002) argues that the introduction of computers in the workplace creates new opportunities for a small number of people, mostly technicians. Yet, for the immense majority, job opportunities have decreased. It is not difficult to understand that as technical skills become more crucial, most managers in publishing houses are more inclined to hire less qualified but technically adept editors instead of experienced editors with fewer technical skills (Zhao 2001). By placing more value on editors' technical skills than on their professional experience and knowledge, managers have successfully degraded editing work, and also, the distinction among editors disappears. As a consequence, positions for 
experienced editors are threatened because managers have realized that in order to minimize wage costs, it is advantageous to employ young editors with adequate technical skills rather than experienced ones, who have traditionally been highly paid.

Third, editors are increasingly challenged by intense work pressures. Managers in most Chinese publishing houses have put enormous pressure on editors with a heavier workload because they assume that the Internet enables editors to finish their work much faster than before. According to the findings from my interviews, it is fairly common for editors to work outside of their regular work hours due to their heavy workload. The growing pressure of working overtime has blurred the boundary between editors' work and leisure time, as well as the boundary between office and home. It is important to note that the added work pressure also comes from enhanced management control over the work process of editors, who face greater surveillance and are increasingly subject to the "electronic panopticon" (Adams and Welsh 2008:221). As a senior editor for more than twenty years, Gao stated in his interview that:

The manager of our publishing house uses his mobile phone to micromanage the book editing process. I frequently receive work-related text messages from him, sometimes even when I am having dinner with my family. I feel extremely depressed because I no longer enjoy the independence and autonomy that I once had. The manager can reach me, whenever he chooses. What is worse, I am expected to keep my mobile phone on even when I am off-duty or on vacation, so that he can assign me new jobs at any time.

Additionally, editors who spend most of their time working on computers are vulnerable to repetitive strain injuries, asthenopia, backaches, and other health problems.

Fourth, while a large amount of information from the Internet provides editors with new sources of knowledge, it has also resulted in information overload (Garrison 2000; Keane and Donald 2002). Given the speed of technological change, editors need to expand and update their professional knowledge as often as possible, and the value of their old knowledge decreases at an incredibly fast speed. In other words, due to information overload, most editors find that their traditional professional skills of editing are not enough, and they are obliged to acquire additional technical skills. For example, in most publishing houses, editors feel the necessity to learn how to use several different software systems to process either text or pictures. They are also responsible for taking on more administration and research work formerly done by more advanced technical workers. As the required skills in the workplace are changing constantly, the abilities of editors to master new skills and to gain up-to-date information become essential; however, they do not necessarily receive higher pay or promotions to higher positions.

\section{Following the political principle in the media marketization process}

As Zhao (1998) maintains, the propaganda model has long been the dominant framework for analyzing the Chinese media industry. According to her definition, the Chinese mass media are controlled instruments of propaganda and mass mobilization, and they have been broadly used to promote changes in the attitudes and behavior of the people. However, in the past thirty years, as a part of the massive state-directed transformation of the Chinese political economy, the media marketization process has widely expanded. In the 
publishing industry, editors are bound, at the core, to serve the political and ideological interests of the state, and meanwhile, they are required to meet the need to generate profit for their companies throughout the media marketization process.

\section{Rise of market competition}

As one of its most profound influences, marketization has reduced institutional dependency of the media on the state, mainly through the commercialization process of the interests, behavior, and finally, structural change of the mass media (Gang and David 2011). Unsurprisingly, marketization has made the Chinese publishing industry essentially relies on market competition for its survival and prosperity, rather than as before, on its hierarchical location within the publishing system and its connection to the state. Responding to the media marketization process, editors have taken the initiative in reorienting themselves to the needs of the market in order to increase their financial resources by all legitimate means, while profit-making becomes an important aim.

To be more specific, when advertising serves as an essential regulative power of a market-oriented media structure, an increasing number of editors concentrate on the informational and entertainment needs of affluent urban consumers-advertisers' most wanted audience. As an editor, Qian observed:

As an editor, I am fully aware of the tremendous impact of the marketization process on the Chinese publishing industry. Most importantly, our publishing house no longer receives direct subsidies from the state, and it must earn revenue in the marketplace.

Advertising has become a major revenue source. Our most popular journal is

"Learning Chinese", a journal that is designed to improve the reading and writing skills of middle-school students and foreigners learning Chinese as a second language. The journal generates substantial profit by selling advertisements to language training institutions. It also prints advertisements for some private optometry clinics that offer a special treatment for myopia.

In other words, when facing increasing market competition, editors become more responsive to readers. With the deepening of media marketization, editors intend to provide information appealing to their audience, such as economic news, news on science and technology, sports news, social news, and useful daily information. Apparently, editors are also paying increasing attention to their interaction with the audience mainly through receiving and responding to its feedback.

\section{Follow the government's leadership}

Although both the roles and functions of the mass media have undergone a series of changes as a result of various substantial ongoing political and social changes associated with the marketization process, the fundamental guideline regarding the mass media never seems to change. That is, in principle, the Chinese mass media remain an instrument of the government, for propaganda and mobilization of the Chinese citizenry (He and Chen 1998).

The Chinese publishing industry still needs to follow the government's leadership. Accordingly, the publishing industry is assigned to advance social development and disseminate information to promote mass mobilization in China's socialist construction. In this situation, the primary task for editors, in Zhao's (2000) view, is not to inform 
the masses but rather to stimulate their action as well as to change their values, beliefs, and behaviors.

Therefore, editors in the publishing industry are supposed to follow the political principle in most cases. Rather than demand more political autonomy from the state, many of the editors have been co-opted by the political and economic elite, and now, they are acting as their supporters. Editors have become quite self-disciplined (Pan 2000; Pan and Lu 2003), carefully picking up the "right" vocabulary in their work. Also, among various tactics to appropriately express their ideas, they often take whatever official rhetoric can offer to selectively justify what they wish to achieve. Zhu indicated in her interview:

Years of regulations and compliance have caused most editors to feel alienated from the government's leading ideology. In order to function under the government's control, editors must possess "professional intuition", a sense of the ideological boundaries of editorial work. Such "professional intuition" helps editors determine what topics and vocabulary are off limits. In my experience, successful editors employ several strategies to ensure good relations with the government: they use quotations from top leaders, they analyze social events from a dialectical materialist perspective, and they avoid absolutism and extremism. Nowadays, finely-tuned "professional intuition" is not only a critical measure of "professional maturity", but more importantly, it saves a lot of trouble.

\section{Growing tension within the propaganda-commercial model}

It has been argued that in the media marketization process, the state plays an important role in directing the development of the mass media through administrative means, such as policies, directives, and individual discretion. Meanwhile, the market creates the need for innovations that put pressure on the state to make corresponding policy changes in the media industry. Therefore, each major Chinese media reform is the result of the interaction between the state and market.

There is, however, a structural contradiction between the state-dominated media system and the ongoing media marketization process in contemporary China, which is manifested in the discursive negotiation between partisanship and professionalism of Chinese media workers. Dong and Shi (2007) maintain that such a contradiction is rather obvious in the Chinese publishing industry and that this contradiction has led to numerous changes for editors, including changes in their identities, the nature of their work, their roles in society, and the principles and criteria used to evaluate and reward their work. Among them, the most fundamental one is that editors face the challenge to generate profit for the publishers, as well as the challenge to expand democracy and to promote political and social reforms, to the extent allowed by the political interests of the state. This remains the core of what Zhao (1998:151) has defined as the "propaganda-commercial model," and it characterizes the context in which editors are situated. Most editors fully realize that changes in their publishing houses do not exist in abstract terms, but in their daily encounters and choices. Luo noted:

The publishing industry has become a special industry with a dual function. On the one hand, like most companies, publishing houses must generate profit, mainly through advertising. On the other hand, they are part of the government's propaganda 
mechanism. As a result, our publishing house is regarded as a company, but it is not under the supervision of industrial and commercial authorities. Instead, it is under the control of propaganda departments.

Due to the industry's dual function, we are "dancing with chains"-in pursuit of economic interests within a restrictive ideological and political framework. Nevertheless, it is interesting to observe that the Chinese publishing industry has witnessed a gradual but clear shift from publishing political materials, like pamphlets of leaders' speeches, to publishing non-political materials, like books on entertainment and public service. Books on fashion, gardening, travelling and cooking have become very popular. Regardless of what material we publish, however, we exercise great creativity to maintain "political correctness". Most importantly, editors and managers in publishing houses, as well as government officials, must exercise considerable "political wisdom" in order to creatively break through political taboos without violating the official "ideological framework".

\section{Smashing of the work-unit system}

Third, the media marketization process is intertwined with the smashing of the work-unit system. Prior to the economic reform introduced by Deng Xiaoping, publishing houses, as work units, provided a living for editors in terms of fair wages and good working conditions, offered extensive social welfare benefits, including pensions, housing, paid sick leave, meal services, recreational facilities, health care, daycare and school, and, most importantly, promoted the Communist ideology to strengthen the Party's leadership (Naughton 2007). Once editors entered publishing houses, they expected to remain there for their careers.

Accordingly, in the work-unit system, Chinese publishing houses were not only economic organizations but also served three non-economic functions, namely, as administrative units, as political vehicles and as social welfare organizations. As a result, editors felt secure in the work-unit system.

First, publishing houses in the work-unit system played an important role in carrying out administrative initiatives and representing individuals. As soon as administrative orders, regulations, and policies of the central and local governments were sent to publishing houses, editors were organized to study government documents. Also, in the work-unit system, editors were tightly connected to the state and society through publishing houses as their work units, which served as mediators between the state and individuals (Lu and Perry 1997). For example, editors who needed their birth certificates notarized by public notary agencies were required to obtain approval from their publishing houses. Also, editors studying abroad who wanted their spouse, children, or parents to visit them needed to receive approval letters from the publishing houses with which they were formerly affiliated.

Second, publishing houses acted as political vehicles. In China, editors' political lives were bound to publishing houses in the work-unit system. According to the provisions of the Constitution effective in 1954, it is stipulated that government leaders should be elected by people's representatives, and representatives should be chosen through primary elections in work units. Therefore, in the work-unit system, editors elected their representatives in the publishing houses, and these representatives elected government leaders. At the same time, the CCP, the Chinese Communist Youth League (CCYL), 
and other democratic parties all had their representative bodies in every work unit. Most editors intended to join either the CCP or the CCYL, for the reason that Party membership was a valuable political asset for their careers. Furthermore, every editor was obliged to attend political study meetings, and in doing so, the political control and management of editors by their work units was achieved. In every Chinese publishing house, editors were organized to study the Party's documents; topmost leaders' speeches; and government administrative orders, regulations, and policies (Warner 2000). In the political study meetings, editors were not only expected to express their attitudes toward the Party's new guidelines but also were asked to examine the deviations of their behavior from the Party's guidelines and to make self-criticism. It is important to note that for editors, both their participation and performance in the political study meetings were considered vital elements in the evaluation process for their job promotion, their salary and bonus rises, and their applications for Party membership.

Third, as social welfare organizations, publishing houses offered a wide array of benefits and services. Such benefits and services included labor insurance, housing, and collective welfare programs and facilities, for example, hospitals and clinics, dining halls, nurseries, recreational facilities, and libraries. Also, some educational institutions were sponsored by work units, such as elementary schools, high schools, technical schools, and even colleges. In the work-unit system, editors were largely dependent on publishing houses, and they felt relatively secure in their work units.

However, interestingly, Stapanek (1992) maintains that in the work-unit system, most editors did not develop a very strong commitment to their publishing houses, as indicated by their low levels of work effort and productivity. Additionally, they were disciplined neither by managerial rules nor procedures. For example, in publishing houses, the absenteeism rate was high, and editors frequently ran personal errands during their work hours. As such, creating a new system of management that would alter such unproductive attitudes and behavior became one of the most important imperatives for reform in the publishing industry.

In such a context, under the banner of "creating a modern enterprise system," the work-unit system was smashed with a complete reshaping of the socialist employment structure. In 1986, the State Council started reconstituting labor relations with the introduction of labor contracts, which encouraged each individual company to hire and fire people according to its financial profitability. Accordingly, in the publishing industry, publishing houses have been given growing power and autonomy to make decisions on personnel and wages, instead of following the previous pattern in which they simply accepted every worker assigned to them by the local labor bureau.

In the publishing industry, the purpose of abandoning the work-unit system was to alleviate the social and political burdens of publishing houses and improve their financial situations in the marketplace. In the work-unit system, the financial burden of providing bonuses, subsidies, and benefits to both employees and retirees was a major contributing element to the fact that numerous publishing houses continued to report financial losses. By the mid-1990s, it was estimated that the value of bonuses, subsidies, and benefits received by editors in publishing houses had been equal to the salaries that they received (Goldman and Macfarquhar 1999). Responding to the tremendous financial burdens, many publishing houses have attempted to require partial and increasing payments for some benefits by editors themselves (including continuing 
education and training, medical services, and housing) and make the distribution of bonuses, subsidies, and benefits become based on performance rather than egalitarianism.

The influences of the marketization process on the social welfare system are so profound that now, even managers in publishing houses, newspaper agencies, and television and radio stations see their roles and conditions as becoming increasingly dependent on market forces, not to mention ordinary workers in the media industry. Therefore, in the publishing industry, the highly politicized publishing houses as work units were despotic because editors were caught in a web of intense "organized dependence" that forced them to rely on their publishing houses to meet almost their every need. In the reform era, with the introduction of market forces, the retreat of politics from everyday economic life has loosened the control that publishing houses once held over their editors. However, at the same time, the reform has also brought about equally despotic working conditions for editors because they are intricately caught in another web of intense "organized dependence" that forces them to rely on market forces. According to Lee (1999), in both state-owned and private enterprises, workers are now disciplined by piece-rate pay scales, strict controls over the work process, and other manifestations of managerial power. Specifically in the publishing industry, the annual incomes of editors are primarily determined by the profit they can generate for their publishing houses, and bonuses constitute a large portion of their incomes.

\section{The internal division of knowledge workers}

As mentioned previously, editors in the Chinese publishing industry are experiencing a serious loss because the privileges they once enjoyed as the "masters" of publishing houses in the work-unit system have been curtailed. Due to the imbalance between labor supply and demand, the bargaining power of editors has declined. Editors have to work long hours for relatively low wages, and they are always reminded that many people are waiting to take their jobs. Despite this, as my interviews reveal, managers in publishing houses have enjoyed growing decision-making power over the distribution of bonuses for editors and the management of human resources.

Alarmingly, in addition to the differences between editors and managers, there is also a sharp rift among editors of the same social group-a growing tension between senior editors and junior editors. Compared with senior editors, most junior editors are confronted with more challenges, including signing contracts based on shorter time periods, taking more challenging tasks with intense work pressure, and receiving fewer opportunities for promotion, but facing more severe financial repercussions if they fail to meet their annual workload or generate the amount of profit specified in their contracts. Therefore, the internal differences within knowledge workers, embodied in the division between editors and managers, as well as the division of editors in the same social group, have widened and become increasingly obvious.

\section{Divisions between editors and managers}

The study of social stratification has been a popular topic of sociological research in China. According to Zhang's (1997) research, since the economic reform, the Chinese working class has been divided into several strata, based on their differences in terms of their access to power, income, occupational popularity, and social status. He also concludes that workers have been separated from employers, who own the means of 
production, and from managers, who control them. For editors in the publishing industry, it comes as no surprise that they consider managers "bosses" and that these managers are no longer part of the working class. In addition, editors deeply resent corruption and misconduct from managers and the unfair treatment that they have received. Zhuang indicated in the interview:

About thirty years ago under the centrally-planned economy, we were all encouraged to participate in management, planning and problem resolution. Since the implementation of the current media reform, however, we are blatantly excluded from management decisions, and we have to passively accept guidance and obey the instructions of our managers.

Critically, in the publishing industry, managers have formed an independent social stratum. From a micro level of analysis, managers in publishing houses have become separated from editors in their social status and rights as defined by law, ideological consciousness and values, based on their social experience. From a macro level of analysis, both privatization and the modern corporate system have encouraged managers to gain power and dominate editors. As such, Sargeson (1999) maintains that the direction of public opinion has become seriously biased, excessively propagandizing managers' positions and roles. The terms "excellent managers" and "star managers" have come into use to honor what managers have contributed to publishing houses, but the positions of editors and their work roles have neither been fully evaluated nor appropriately affirmed.

There are two profound influences brought about by the division between editors and managers. First, most editors' enthusiasm for production, once encouraged by management participation, is now genuinely necessitated by productivity-related wage payments and the threat of dismissal. As a response, while losing many of their privileges relative to other social groups, most editors are paying growing attention to their personal interests and incomes. Editors are inspired to pursue personal economic interests and address their rights to earn money in the marketplace given that the work-unit system in the centrally planned economy has been smashed. Such concepts as cost, price, and profit have become important metrics for both editors and managers when minimum labor costs are sought.

Second, with the enlarged gap between editors and managers in power, the personal connections between editors and managers, also known as guanxi, have come to play a significant role in the publishing industry. Editors' access to both material resources and opportunities is largely regulated by their relative positions in the highly complex and entangled networks of personal connections. Therefore, they are pressured to establish extensive and intimate personal connections to managers with the purpose of gaining personal benefits.

\section{Divisions of editors in the same social group}

In the work-unit system, workers in the same social group may previously have had competing and contradictory interests because of the unequal allocation of resources in the socialist state. Nevertheless, due to the fact that all workers were the owners of state-owned enterprises, their competing and contradictory interests were nonantagonistic. According to my interviews in both publishing houses, however, the nonantagonistic relations among editors have been largely challenged by the reform of the 
publishing industry, especially when publishing houses are changing from public institutions to companies.

Essentially, senior editors and junior editors are treated differently in publishing houses, leading to a growing tension between them. First, senior editors and junior editors sign contracts based on different time spans. In the publishing houses I have examined, junior editors sign contracts once every year in their first three years. Beginning in their fourth year, only those "excellent" (well-behaved) editors are allowed to sign contracts once every three years. Maybe a few years later, they can sign contracts once every five years, depending on their performance. Meanwhile, senior editors initially sign their contracts once every three years according to the Labor Law effective in 1995. Afterwards, they sign contracts that guarantee their lifetime employment. Contracts for senior editors are more symbolic in meaning than real in their effects. They sign contracts only to conform to the requirements of the Labor Law.

Second, senior editors are often given fewer demanding tasks by the managers in publishing houses. Since the beginning of the reform in the publishing industry, in most cases, senior editors have been assigned to edit textbooks because publishing textbooks is exceedingly profitable, and the incomes of editors are basically determined by the generated profit. However, managers have always assigned more demanding tasks to junior editors. For example, in the publishing houses I have examined, junior editors are mainly responsible for publishing books that introduce new science and technology. It is difficult to predict how many people will be interested in books of this kind. As the market is rather unpredictable, profit cannot be guaranteed. In the interview, Huang described this situation:

In our publishing house, senior editors are always in charge of editing and publishing conference pamphlets and government guidebooks. They do not have to worry about the sales of those publications because most of them are purchased in advance, and substantial profit is guaranteed. Junior editors are assigned to edit books on very specific areas of science and technology. For example, the manager has assigned me to edit a book on contemporary scientific development in diabetes research. Since such books have incredibly limited target readers, they are unlikely to generate huge profit. I am not the only person who complains about the unfairness of giving "easy" tasks to senior editors and "challenging" tasks to junior editors. My colleagues, who are responsible for "seasonal" publications, such as books on knitting, are pressured to meet fixed deadlines so that the books can be published before they are in high demand. Very often, my colleagues have to work overnight, and sometimes they work 17 hours a day.

Third, both the reward and punishment systems are different for senior editors and junior editors. In terms of the reward system, senior editors easily get promoted. In the publishing industry, senior editors are more respected due to their seniority instead of their professional skills and abilities because seniority is widely honored according to the Chinese tradition. As for the punishment system, on the one hand, senior editors, most of who lack marketing knowledge, can hardly make enough profit specified in their contracts. They are, however, allowed to stay in publishing houses by the managers even if they are not working hard, so long as they do not make any trouble for the managers' control and management of other editors. On the other hand, the profit 
that junior editors generate for publishing houses is carefully calculated and mainly determines their incomes. That is to say, the annual incomes of junior editors can be largely reduced if they fail to earn the amount of profit specified in their contracts. As such, there is no doubt that junior editors experience tremendous work pressure to ensure that their books sell well, and they need to be extremely sensitive to the demands of readers.

Indeed, the interviews reveal that in the publishing industry, both senior editors and junior editors are facing the same challenges brought about by the media marketization process. However, even though senior editors are less competent than junior editors, precisely speaking, it is the junior editors who are pressured to sign contracts based on shorter time periods, take more challenging tasks with intense work pressure, and obtain fewer chances to be promoted. Moreover, they receive more severe financial repercussions if they fail to meet their annual workload or to generate the amount of profit specified in their contracts. Therefore, a broader fragmentation of employment has emerged when "differences and inequalities in terms and conditions are created between workers (in my case, editors) who were previously employed under the same conditions" (Flecker et al. 2009:32).

\section{Conclusions}

The understanding of social transformation is connected to the mutual constitution of structure and agency. The Chinese publishing industry, since the economic reform of the late 1970s, has experienced enormous changes in every aspect of editors' lives, ranging from their employment and living conditions to their social relations. The fundamental social changes, including technological, political, and economic ones, and, most importantly, changes in class relations and power dynamics, have brought about four critical challenges for editors. These challenges are the following: challenges related to technological change, challenges of how to follow the political principle in the media marketization process, challenges brought about by the smashing of the work-unit system, and challenges resulting from the internal division within knowledge workers. More importantly, in my analysis of the precariousness of knowledge workers through the examination of editors in the Chinese publishing industry, I address the challenges facing them as a social class and the understanding of their common problems, interests, prospects, and responses, as well as their relations to other types of workers. This analysis is also essential to our understanding of the wider social relationship between communication and the institutional power structure where editors, and knowledge workers in general, are situated.

Abbreviations

CCP: Chinese Communist Party; CCYL: Chinese Communist Youth League

Competing interests

The author declares that he has no competing interests. 
Received: 12 January 2017 Accepted: 11 April 2017

Published online: 18 April 2017

\section{References}

Adams, Tracey, and Sandy Welsh. 2008. The Organization and Experience of Work. Toronto: Thomson and Nelson. Bell, Daniel. 1999. The Coming of Post-Industrial Society. New York: Basic Books.

Berg, Bruce. 2007. Qualitative Research Methods for the Social Sciences, 6th ed. Boston: Allyn and Bacon.

Braverman, Harry. 1974. Labor and Monopoly Capital. New York: Monthly Review Press.

Castells, Manuel. 1996. The Rise of the Network Society. Cambridge: Blackwell.

Chang, Kai. 1998. Globalization and China's Labor Legislation, Asian Labor (September/December), 33-45.

Denzin, Norman, and Yvonna Lincoln. 2008. The Landscape of Qualitative Research, 3rd ed. Los Angeles: Sage.

Dong, Steve Guanpeng, and Anbin Shi. 2007. Chinese News in Transition. In Media on the Move, ed. Thussu Daya Kishan, 182-197. London and New York: Routledge.

Flecker, Jörg, Ursula Holtgrewe, Annika Schönauer, and Stavros Gavroglou. 2009. Value Chain Restructuring and Company Strategies to Reach Flexibility. Leuven: HIVA.

Gang, Qian, and David Bandurski. 2011. China's Emerging Public Sphere. In Changing Media, Changing China, ed. Susan Shirk, 38-76. New York: Oxford University Press.

Garrison, Bruce. 2000. Journalists' Perceptions of Online Information-gathering Problems. Journalism and Mass Communication Quarterly 77(3): 500-514.

Giddens, Anthony. 1984. The Constitution of Society: Outline of a Theory of Structuration. Berkeley: University of California Press.

Goldman, Merle, and Roderick Macfarquhar. 1999. The Paradox of China's Post-Mao Reforms. Cambridge and London: Harvard University Press.

He, Zhou, and Hualin Chen. 1998. The Chinese Media. Hong Kong: The Pacific Century Press.

Ho, Virginia Harper. 2003. Labor Dispute Resolution in China. Berkeley: Institute of East Asian Studies.

Hobsbawn, Eric. 1973. Karl Marx's Contribution to Historicography. In Ideology in Social Sciences, ed. Blackburn Robin, 265-283. New York: Vintage.

Hong, Yu. 2008. Class Formation in High-tech Information and Communications as an Aspect of China's Reintegration into Transnational Capitalism, Ph.D. dissertation, Department of Communication, University of Illinois at Urbana-Champaign.

Jin, Ye. 1998. The Corruption in Various Social Strata. Zhuhai: Zhuhai Press.

Keane, Michael, and Stephanie Donald. 2002. Responses to Crisis. In Media in China, ed. Stephanie Hemelryk Donald, Michael Keane, and Yin Hong, 200-211. New York: RoutledgeCurzon.

Lee, Ching-Kwan. 1999. From Organized Dependence to Disorganized Despotism. The China Quarterly 157(3): 44-71.

Lee, Ching-Kwan. 2007. Pathways of Labor Activism. In Chinese Society, 3rd ed, ed. Elizabeth Perry and Mark Selden, 57-79. London and New York: Routledge.

Liu, Yufang. 2001. On Changes Occurring within the Structure of the Working Class, The Workers' Daily. December 26.

Liu, Chang-de. 2006. De-skilling Effects on Journalists. Canadian Journal of Communication 31: 695-714.

Lu, Xueyi. 2002. Study Report on the Stratum in Contemporary China. Beijing: Social Science Press.

Lu, Xiaobo, and Elizabeth Perry. 1997. Danwei: The Changing Workplace in Historical and Comparative Perspective. New York and London: M.E. Sharpe.

McKercher, Catherine. 2002. Newsworkers Unite: Labor, Convergence and North American Newspapers. Lanham: Rowman and Littlefield.

Mosco, Vincent. 2006. The Laboring of Communication. Canadian Journal of Communication 31: 494-497.

Mosco, Vincent. 2008. Knowledge Workers of the World! Unite? Canadian Journal of Communication 33: 121-125.

Mosco, Vincent. 2009. The Political Economy of Communication, 2nd ed. London: Sage.

Mosco, Vincent, and Catherine McKercher. 2008. The Laboring of Communication. Lanham: Lexington Books.

Naughton, Barry. 2007. The Chinese Economy. Cambridge and London: MIT Press.

Pan, Zhongdang. 2000. Improvising Reform Activities. In Power, Money, and Media, ed. Chin-Chuan Lee, 68-111. Evanston: Northwestern University Press.

Pan, Zhongdang, and Ye Lu. 2003. Localizing Professionalism. In Chinese Media, Global Contexts, ed. Chin-Chuan Lee, 215-236. London and New York: RoutledgeCurzon.

Ross, Andrew. 2009. Nice Work If You Can Get It. New York: New York University Press.

Sargeson, Sally. 1999. Reworking China's Proletariat. New York: St. Martin's Press.

Schiller, Herbert. 1973. The Mind Managers. Boston: Beacon Press.

Stake, Robert. 2000. Case Studies. In Handbook of Qualitative Research, 2nd ed, ed. Norman Denzin and Yvonna Lincoln, 435-454. Thousand Oaks: Sage.

Stepanek, James. 1992. China's Enduring State Factories. In China's Economic Dilemmas in the 1990s, ed. Joint Economic Committee, Congress of the United States, 440-453. Armonk: M.E. Sharpe.

Vallas, Steven, William Finlay, and Amy Wharton. 2009. The Sociology of Work. New York: Oxford University Press.

Warner, Malcolm. 2000. Changing Workplace Relations in the Chinese Economy. London and New York: St. Martin's Press. Wortzel, Larry. 1987. Class in China. Westport: Greenwood Press.

Yin, Robert. 2009. Case Study Research, 4th ed. Beverly Hills: Sage.

Zhang, Yunqiu. 1997. An Intermediary. Journal of Contemporany China 6(14): 139-152.

Zhang, Zihui. 2004. To Advance the Publication Reform from Both Institutional and Technological Perspectives. Journal of China Publishing 12: 37-39.

Zhang, Wangjun, and Jianfeng Peng. 2001. Motivation System in Chinese Knowledge Enterprises. Science Research Management 22(6): 90-96.

Zhao, Yuezhi. 1998. Media, Market, and Democracy in China. Urbana and Chicago: University of Illinois Press.

Zhao, Yuezhi. 2000. From Commercialization to Conglomeration. Journal of Communication 50(2): 3-26. 
Zhao, Yuezhi. 2001. Media and Elusive Democracy in China. The Public/Javnost 8(2): 21-44.

Zhu, Guanglei. 1994. Great Division Breeds New Organization. Tianjin: Tianjin People's Press.

Zhu, Xixi, and Changzhen Dai. 2009. Knowledge Workers in the Socialist Market Economy. China Economic and Trade Herald 24: 103-110.

Submit your manuscript to a SpringerOpen ${ }^{\circ}$ journal and benefit from:

- Convenient online submission

- Rigorous peer review

- Immediate publication on acceptance

- Open access: articles freely available online

- High visibility within the field

- Retaining the copyright to your article

Submit your next manuscript at $\boldsymbol{\nabla}$ springeropen.com 